\title{
AT-TAFETRE
}

VOLUME 14 NOMOR 1 TAHUN 2021

10.32505/at.vl4i2.1936

\section{Epistemologi Tasawuf Hamzah Fansuri dalam Kitab Sharb Al-Ashîqîn}

\author{
Ramli
}

Dosen STAIN Teungku Dirundeng Meulaboh ramli@staindirundeng.ac.id

\begin{abstract}
The highest knowledge of the Sufis is ma'rifah which is obtained through disciplinary practice, through riyadhah and mujahada which are here referred to as Sufi epistemology. These paths are cultivated in a disciplined, methodological and objective manner so as to enable the Sufis to compile their treatises in a standard manner. As one of the most famous scholars in the archipelago, Hamzah Fansuri in the book Sharb Al-Ashiqun also compiled standard treatises regarding this Sufi path. Through this philosophical analysis, Hamzah Fansuri's model of Sufism epistemology is explained. The results of this study indicate that to reach the state of knowledge, a person must take spiritual steps, be under the guidance of a teacher, lead a simple life and always put their trust in Allah SWT.
\end{abstract}

Keywords: Hamzah Fansuri, Sufi Epistemology and the book Sharb Al-Ashiqün.

Abstrak: Pengetahuan tertinggi kaum sufi adalah ma'rifah yang diperoleh melalui laku disiplin, melalui riyadhah dan mujahadah yang disini disebut sebagai epistemology sufi. Jalan-jalan tersebut dibina secara disiplin, metodologis dan objektif sehingga memungkinkan kaum sufi menyusun risalah-risalahnya secara baku. Sebagai salah seorang ulama tersohor di nusantara, Hamzah Fansuri dalam kitab Sharb Al-Ashiqünjuga menyusun risalah baku berkenaan dengan jalan sufi tersebut. Melalui analisis filosofis disini dipaparkan model epistemologi tasawuf Hamzah Fansuri. Hasil dari penelitian ini menunjukkan bahwa untuk mencapai maqam pengetahuan, seseorang harus menempuh tangga-tangga spiritual, berada dalam bimbingan guru, menjalani hidup sederhana dan senantiasa bertawakal kepada Allah SWT.

Kata kunci-Hamzah Fansuri, Epistemologi Tasawuf dan Kitab Sharb Al-Ashiqŭn kata kunci,

\section{PENDAHULUAN}

Semarak studi filsafat Islam di tanah air menunjukkan kecenderungan pada studi epistemologi. Namun, geliat epistemologi kali ini justru datang dan dipengaruhi setidaknya oleh Persia dan Barat. Pengaruh Persia misalnya dimulai dari tiga guru besar filsafat Persia yaitu Ibnu 'Arabi, Suhrawardi dan Mulla Sadra yang dibawa oleh Allamah Thaba'thaba'i, Murtadha Muthahari, Syed Hosein Nasr dan Mehdi Ha'iri Yazdi. Pengaruh Barat misalnya datang dari Descartes, Hegel, Nietzsche, Derrida hingga Foucalt. Pengaruh Filsafat Persia merangsak masuk ke Indonesia melalui jalur Iran dan Malaysia sedangkan filsafat Barat, datang karena kuatnya pengaruh Amerika, Jerman dan Prancis pada khazanah pemikiran filsafat Islam tanah air.

Sayangnya, geliat epistemologi tersebut berbarengan dengan kegagalan menggali ghazanah lokal yang dimasa terdahulu telah memberikan sinyal-sinyal keilmuan yang berkualisas dan original. Kita kenal pemikir Aceh seperti Hamzah 
Fansuri, Nũruddîn Ar Rânîrî hingga Abdur Ra'ũf As Sinkilî, yang kesemuanya membawa diskursus yang utuh berkenaan dengan konsep keilmuan yang dianut oleh masing-masing, termasuk persoalan epistemologi. Pada Khazanah Aceh kontemporer kita mengenal Abu Bakar Atjeh, Ali Hasyimi dan Hasbi Ashdiddiqie, yang masing-masing juga memiliki bangunan keilmuan yang utuh. Makna bangunan keilmuan yang utuh di sini adalah bahwa masing-masing pemikir memiliki defenisi dan karakter keilmuan yang jelas (ontologi), sumber keilmuan dan metodologi berfikir (epistemologi) hingga implikasi baik itu praktis maupun teoritis dari bangunan keilmuan yang telah dibangun (aksiologi).

Jadi, atas dasar semangat keilmuan dalam mencari epistemologi tasawuf bercorak nusantara, disini dicoba lakukan pembacaan ulang atas karya Hamzah Fansuri, khususnya kitab Sharb Al-Ãshiqîn (Miswari, 2016: 24-27). Diharapkan, pembacaan ini akan menghasilkan rekonstruksi epistemologi tasawuf yang mapan dan memberi jawaban bagi persoalan-persoalan spiritualitas dan keumatan.

\section{METODE PENELITIAN}

Penelitian ini menggunakan telaah pustaka atas karya Hamzah Fansuri dan karya-karya lain yang terkait. Teori penelitian yang digunakan adalah teori epistemologi pengetahuan A. Sonny Keraf dan Mikhael. Dua yang membagi pengetahuan kepada dua kategori yakni context of discovery dan context of justification, yakni bagaimana pengetahuan ditemukan dan divalidasi (Dua, 2006: 154-158). Beberapa pengkaji cenderung mengetengahkan epistemologi tasawuf dalam diskursus validasi. Sebut saja Mehdi Ha'iri Yazdi yang mencoba menalar epistemologi sufi dalam ruang validitas ilmiah kontemporer (Mehdi Ha'iri Yazdi, 2003) dan Syaifan Nur yang menekankan epistemologi sebagai telaah atas "karakteristik sufistik" dan "telaah rasional" untuk menemukan basis ilmiah dari ilmu tasawuf (Nur, 2012: 135-136).

Diskursus epistemolgi dalam penelitian ini lebih mirip dengan M.Ainul Abed Syah yang menalar epistemologi sufi langsung pada pokok persoalan kesufian dari kontemplasi (suluk) hingga sampai pada puncak 'irfânî (Shah, 2012: 155-158). Adapun analisis data dilakukan dengan pengumpulan data-data relevan untuk kemudian direduksi dan disajikan serta ditarik satu kesimpulan penelitian.

\section{HASIL DAN PEMBAHASAN}

\section{A. Biografi Hamzah Fansuri}

Hamzah Fansuri (w. 1527) adalah seorang tokoh besar putera Aceh sendiri yang terpelajar di lingkungan agama dan kesusastraan yang tampil di pertengahan kedua abad ke XVI (Said, 1981: 247). Hamzah Fansuri lahir di negeri Barus atau dulunya juga dikenal sebagai Fansur. Sebagian pengkaji sejarah Ia hidup pada masa pemerintahan Kerajaan Aceh Darussalam pada abad ke-16 dan 17 Masehi. Kala itu, 
negeri Barus sudah masuk dalam wilayah kekuasaan Kerajaan Aceh Darusssalam. Dalam sebuah catatan yang ditulis oleh Ali Hasjimi, ada tradisi bagi orang-orang alim dari negeri Barus untuk merantau dan mengembangkan agama di daerah sekitarnya. Di antara mereka, Hamzah Fansuri dan saudaranya, Ali Fansuri, pergi ke Singkil dan mendirikan lembaga pendidikan disana (Hadi, 2001: 12).

Penyebaran ajaran tasawuf Hamzah Fansuri, tidak terlepas dari dukungan para sultan yang melindunginya ('Alâ Al-Dîn Ri'âyaḥ Syah, berkuasa 1589-1602 M dan Iskandar Muda, berkuasa 1607-1636 M). Tidak dapat dipungkiri bahwa peran politik selalu memberi pengaruh bagi berkembangnya suatu ajaran. Azra menyebutkan, tulisan-tulisan Hamzah dan Shams Al-Dîn Al-Sumatrâ'î (w. 1630 M) memberi dorongan lebih jauh pada kecenderungan ini. Dengan kedudukan mereka sebagai Shaikh Al-Islâm di Kesultanan Aceh, mereka dapat menyebarkan pengaruh yang besar (Azra, 2004: 201). Hal ini mungkin saja terjadi karena dalam catatan sejarah, kekuasan atau politik dianggap cukup ampuh dalam menyebarkan atau memusnahkan suatu faham. Dalam tahap selanjutnya, ajaran Fansuri-pun hampir musnah juga dikarenakan aspek politik. Ketika itu, dukungan kesultanan yang dipegang oleh Sulthan Iskandar Thânî (berkuasa 1636-1641 M) dialihkan kepada Shaikh Nũr Al-Dîn Al-Rânîrî (w.1658 M) (Azra, 2004: 212)

Mohammad Said mengemukakan hal yang berbeda. Menurutnya, penyebaran ajaran tasawuf Hamzah Fansuri yang masih subur hingga saat ini disebabkan oleh kemampuan membungkus ajarannya dengan bahasa yang indah dan mudah difahami. Mohammad Said meyakini bahwa hal tersebut bisa terjadi karena syair-syairnya mudah dihafal dan bisa difahami oleh setiap pendengar yang kebanyakan dari kalangan awam. Bahkan Said meyakini, ajaran yang dibawa Hamzah bahkan mampu mengislamkan para pendengarnya (Said, 1981: 248).

Hawash Abdullah menduga bahwa Hamzah Fansuri juga merupakan seorang ahli bahasa. Hawash meyakini setidaknya Hamzah Fansuri menguasai tiga bahasa yaitu bahasa Arab, Persia dan Melayu (Abdullah, 1987:30). Pengetahuan Hamzah mengenai bahasa Arab dan Persia juga diakui oleh oleh Abdul Hadi dan L.K Ara. Keduanya menyebutkan bahwa selain menguasai bahasa Melayu, Hamzah juga mahir berbahasa Persia dan Arab. Penguasannnya yang baik terhadap bahasa Arab dan Persia membuat Hamzah Fansuri mampu mengakses sumber-sumber tasawuf terkemuka yang kebanyakan ditulis dalam bahasa Arab dan Persia. Hamzah Fansuri dalam menuliskan karya-karya tasawuf berbahasa Melayu terkadang tidak dapat melepaskan diri dari pengutipan istilah-istilah berbahasa Arab dan Persia (Hadi, 1996). Hasilnya, beberapa dari kutipan tersebut kemudian menjadi dikenal khalayak dan meresap kedalam kosa kata dan memperkaya khazanah kesusasteraan Melayu.

Pada masa Al-Rânîrî terjadi pemusnahan besar-besaran karya tasawuf Hamzah Fansuri dan perburuan atas pengikut-pengikutnya. Akibatnya, sedikit karya Hamzah Fansuri maupun karya serupa berkenaan dengan tasawuf 
wujúdiyah yang dapat diselamatkan, (Abdul Hadi, 1996)(Hadi, 1996:13). Hingga hari ini hanya ada tiga risalah tasawuf dan beberapa bait puisi Hamzah Fansuri yang dapat dikonfirmasi keberadaannya yakni Asrâr al-'Árifîn, Sharb al-'Áshiqîn dan Al Muntahî. Terakhir, Wan Muhammad Saghir Abdullah, seorang peneliti teks-teks sufi Melayu memasukkan beberapa karya lagi yang diklaim sebagai karya Hamzah Fansuri yaitu KashfSirrî Tajalllis Shibyân dan Kitâb fî Bayân Al-Ma'rifah (Saghir, 1996).

\section{B. Deskripsi Kitab Sharb Al-Ashiqūn}

Sharb al-'Āshiqîn dapat diterjemahkan sebagai minuman (anggur atau arak) bagi orang-orang yang sedang mencapai mabuk spiritual berahi /'ishq (the Drink of Lovers). Snouck Hurgronje memiliki salah satu naskahnya dan sekarang naskah tersebut disimpan di Perpustakaan Leiden (MS Cod. Or. 7291). Naskah lain yang sepertinya lebih lengkap ditemukan di daerah Banten diakhir abad ke 19, juga tersimpan di Perpustakan Leiden (MS. Cod. Or. 2016). Upaya transliterasi pertama, sejauh yang dapat ditelusuri oleh beberapa peneliti adalah Doorenbos dan kemudian Syed Muhammad Naquib Al Attas, yang melengkapi transliterasinya dengan translate berbahasa Inggris (Abdul Hadi W.M, 2011: 146-147). Terakhir, naskah Sharb al-'Āshiqîn dilaporkan juga terdapat di perpustakaan kuno Abu Dahlan Tanoh Abee No. 640 F Aceh Besar (Syarifuddin, 2011: 34).

Seiring dengan penyebaran ajaran Tasawuf Hamzah Fansuri ke tanah Jawa, kitab ini juga diterjemahkan disana. Pada akhir abad ke 17, ditemukan naskah Sharb al-'Āshiqîn berbahasa Jawa. Naskah versi Jawa tersebut dijumpai di Banten dan merupakan kepunyaan Sulthan Abu Al Mạ̣asîn Zayd al ‘Ābidîn, Raja Banten dari tahun 1690 sampai 1733 M. Naskah berbahasa Jawa ini kemudian disalin dan disunting serta diterjemahkan ke dalam Bahasa Inggris oleh Drewes dan Brakel (Hadi, 2011: 146-147).

Selain itu, terdapat versi ringkas dari kitab Sharb al-'Āshiqîn, yaitu kitab yang bernama Zînah Al Wạhidîn. Terdapat perbedaan diantara keduanya, misalnya dalam kitab Zînah Al Wâhidîn tidak terdapat muqadimah pendahuluan seperti dalam kitab Sharb al-'Āshiqîn. Namun yang membedakan keduanya hanya bagian awal pembahasan dan penambahan beberapa kata-kata pembuka dan penutup. Dalam Zînah Al Wâhidîn tidak terdapat muqâdimah seperti yang ada dalam Sharb al-'Asyiqîn. Selain itu, sedikit perbedaan redaksi pada awal-awal paragraf dimana kata-kata pembuka seperti "ketahui," "Kerana itu," "Adapun Kata Nabi" dan lain-lain yang terdapat dalam naskah Sharb al-'Āshiqîn, tapi tidak terdapat dalam Zînah Al Wâhidîn. Namun secara umum, subtansi dan pemahaman ajaran wujúdiyah dalam Zînah Al Wâhidîn, sama dengan Sharb al-'Ashiqîn, dan nyaris tidak mengalami pengurangan apa-apa (Al-Attas, 1970: 297-328). 
Kitab Sharb al-'Āshiqîn ini kemudian ditemukan dalam versi Bahasa Jawa. Fakta ini mengindikasikan pengaruh kuat ajaran tasawuf Hamzah Fansuri di Pulau tersebut. Transliterasi naskah Sharb al-'Āshiqinn dalam bahasa Jawa ini dapat dilihat dalam buku G. W. J. Drewes and L. F. Brakel yaitu The Poems of Hamzah Fansuri (Brakel, 1986: 226-273).

Sharb al-'Āshiqîn terdiri dari tujuh yaitu: Bab pertama berbicara tentang amalan sharî́ah yaitu ketika perbuatan seseorang mengikuti tuntunan rasulullah SAW, melaksanakan kewajiban dan menjauhi larangan agama. Menurut Hamzah, seorang ahli sulũk tidak akan mengabaikan kewajiban-kewajiban sharî‘ah yang merupakan salah satu tiga pilar tuntunan Nabi. Tiga pilar tersebut adalah sharî‘ah, tarîqah dan haqîqah. Proses sulũk akan menjadi sempurna jika sang sâlik memperhatikan ketiga elemen ini (Al-Attas, 1970:302).

Bab kedua berbicara tentang amalan tarîqâh yaitu proses pendakian spiritual (maqâmât) yang dibagi ke dalam tiga tingkatan yaitu taubah, tark al-dunyâ (zuhd/asketis) dan tawakkal ( Al-Attas, 1970: 304-306). Hamzah Fansuri dalam bab ini sepertinya menyamakan antara țarîâh (proses perjalanan spiritual) dan maqâm (pemberhentian/station/stage). Ini terlihat dari tingkatan țarîqâh Hamzah Fansuri tak lain merupakan tingkatan maqâm. Namun ini tidak sepenuhnya keliru, karena pada dasarnya, țarîqâh juga merupakan proses perjalanan spiritual menempuh maqâm (Simuh, 2002:40).

Bab ketiga berbicara tentang amalan haqîqah yaitu ketika dia melihat sesuatu, maka dilihatnya pula Allah di dalamnya. Hamzah membagi ahl haqîqah ke dalam dua bagian, yaitu satu mereka yang tetap memiliki kehidupan duniawi (anak, istri dan harta) namun hatinya tidak terpaut dengannya. Dia tidak bergembira dengan mendapatkan mereka, dan tidak pula bersedih ketika kehilangan mereka. Adapun ahl haqîqah yang kedua yaitu mereka yang meninggalkan dunia secara total dan hanya menyerahkan kehidupannya kepada Allah SWT (asketis ekstrim) (Al-Attas, 1970 :304-310). Pada sejarahnya memang ada dua model pengamal sufi. Ada yang mengamalkannya secara moderat seperti Junaid al-Baghdâdř, Jalal Al-Dǐn Al-Rǔmǐ dan Al-Ghazâlǐ, dan ada juga pengamal sufi yang ekstrim seperti Râbi'ah Adhawiyah dan Ibrâhim ibn Adhâm.

Bab keempat, berbicara tentang ma'rifah Hamzah Fansuri. Bab ini berbicara tentang konsep 'muhît' (Fushilat 4l:54). Hamzah membedakan konsep muhît para 'ulama (ulama kalam/teolog) dan ahl sulük (ahli sufi). Menurut para 'ulama, Allah meliputi alam semesta dengan ilmunya. Namun menurut ahl sulük, Allah meliputi semesta dengan Dzat dan Ilmu-Nya karena Dzat dan Ilmu Allah SWT adalah satu dan tidak bercerai. Maka disini Hamzah menafsirkan 'muhît' dengan makna 'hampir/berhampiran' (kedekatan dengan Tuhan/nearness to God). Artinya, Allah memang memiliki 'kedekatan,' dengan semua ciptaannya. Namun, kedekatan Allah 
- antara satu makhluk dengan makhluk yang lainnya - itu berbeda-beda (Al-Attas, 1970: 304-311). Selain itu, kedekatan Allah dengan hambanya adalah kedekatan Dzat yang terperi (Dzat yang mengatribut) dan kedekatan Ilmu.

Hamzah kemudian membagi makna kedekatan (hampir) ke dalam empat yaitu kedekatan makan (tempat), kedekatan zaman (masa), kedekatan sifat dan kedekatan dzat. Anehnya, Hamzah hanya membuat analogi tiga model kedekatan (tempat, masa dan sifat) dan tidak membuat analogi (perumpamaan) kedekatan Dzat. Kami menduga itu karena Hamzah khawatir konsep kedekatan Dzat tidak akan mampu difahami oleh orang lain (Al-Attas, 1970: 304-312). Selain itu menurut Al-Attas, kedekatan Dzat tidak dijelaskan karena ia hanya dapat diketahui oleh mereka yang sudah mencapai maqam ma'rifah. Beberapa analogi Hamzah tentang kedekatan (hampir) misalnya

1. Kedekatan zaman seperti zaman kita lebih dekat kepada zaman Nabi Muhammad SAW daripada zaman Nabi Isa as.

2. Kedekatan tempat seperti Bulan lebih dekat jaraknya kepada kita daripada Bintang Mushtârî (Venus).

3. Kedekatan sifat seperti Ba Yazid (Abu Yazid) lebih mendekati sifat Rasulullah daripada 'Ahtâbah dan Shaibah. Walaupun keduanya hidup sezaman dengan Rasulullah tapi dari segi sifat - menurut Hamzah - sifat Abŭ Yazîd lebih mendekati kepada sifat Rasulullah SAW (Al-Attas, 1970: 312).

Jadi, dalam prespektif muhît, setiap hamba memiliki dimensi kedekatan antara dirinya dengan Tuhan, baik itu orang yang beriman maupun orang yang kafir. Baik itu kekasih Allah semisal Nabi, maupun musuh Allah sekelas Iblis atau Fir'aun. Dalam prespektif muhît mereka tetap memiliki kedekatan. Hanya saja, intensitas dari kedekatan tersebut berbeda satu sama lain. Intensitas (kedudukan) kedekatan hamba yang beriman dengan Tuhannya, tentu berbeda dengan hamba yang kafir, begitu seterusnya. Intinya, intensitas kedekatan dalam prespektif muhît, berkaitan erat dengan derajat keimanan dan ketakwaan hamba yang bersangkutan kepada Allah SWT.

Bab kelima berbicara tentang tazalliât Allah SWT (penyingkapan/ graduation). Tahap ini terdiri dari 5 tingkatan tajallî yaitu: Pertama la ta'yun, dimana akal, dialektika, ilmu dan 'irfan kita tidak akan pernah mencapai Dzat Allah SWT. Kedua ta'yun awwal yaitu 'ilm, wujúd, shuhúd dan núr Allah SWT. Ketiga ta'yun tsâni yaitu a'yân thâbithah, thuwwâr al 'ilmiyyah, haqîqah al asyâ dan rüh idhâfî. Keempat ta'yun thâlis yaitu ruh insan, ruh hewan dan ruh nabati (tumbuh-tumbuhan). Kelima ta'yun râbi' dan dan ta'yun khâmis yaitu alam semesta (makhlŭqât) dengan berbagai tingkatannya (Al-Attas, 1970: 315-320). Ajaran ta'yun ini dalam tradisi metafisika Nusantara disebut juga sebagai martabat yang lima. 
Bab keenam berbicara tentang Sifat Allah SWT. Hamzah menuliskan bahwa sifat Qadim Allah SWT ada tujuh yaitu: Hayât, 'Ilm, Iradât, Qudrâh, Kalâm, Sama', dan Bashar. Pada bab ini juga dijelaskan sifat Jalâl (perkasa) dan Jamâl (indah) Allah SWT. Bahwa Allah menciptakan yang negatif dengan Jalâl -Nya dan menciptakan yang positif dengan Jamâl -Nya (Al-Attas, 1970:321-324). Di sini dipahami bahwa setiap Jalâl dan Jamâl Allah membawahi tujuh sifat yaitu Hayât (Maha Hidup), 'Ilm (Maha Mengetahui), Iradât (Maha Berkehendak), Qudrâh (Maha Kuasa), Kalâm (Maha Berkata-kata), Sama (Maha Mendengar)', dan Bashar (Maha Melihat).

Bab ketujuh berbicara tentang 'ishq (berahi/gairah) dan sukr (mabuk). Hamzah menjelaskan kata 'ishq sebagai berahi dan sukr sebagai mabok. Mereka yang mencapai berahi, keinginannya sering bertentangan dengan akal. Jika akal ingin kehidupan maka berahi menginginkan kematian; jika akal menginginkan kenyang maka berahi menginginkan lapar dan begitu seterusnya. Sedangkan mabok adalah suatu keadaan ekstase dimana seseorang tidak mampu lagi mengendalikan diri. Ia terbawa masuk ke dalam keadaan spiritual sehingga keluar dari mulutnya katakata syatahat, seperti ungkapan Al-Hallaj, “Ana al-haq" (Al-Attas, 1970:325-328). Walhasil, seorang yang berada dalam 'ishq tidak lagi menjadikan akal sebagai pertimbangan perbuatan. Sedangkan orang yang mengalami sukr, telah terbuka baginya pintu rahasia ma'rifah.

\section{Epistemologi Tasawuf Hamzah Fansuri dalam Kitab Sharb Al-'Ashiqūn}

Epistemologi adalah bidang filsafat yang membahas berkenaan dengan teoriteori pengetauan (theory of knowledge). Epistemologi berasal dari bahasa Yunani episteme dan logos. Episteme artinya "pengetahuan", sedangkan logos artinya "teori" atau "ilmu". Pada mulanya, epistemologi merupakan istilah tekhnis filsafat. Lalu kemudian menjadi istilah tekhnis bagi ilmu pengetahuan lainnya. Seiring dengan upaya saintifikasi ilmu sufi, istilah epistemologi juga masuk dalam khazanah peneliti tasawuf. Epistemologi ketika masuk dalam "teori tasawuf" maka ia menjadi sama dengan epistemologi ilmu-ilmu lainnya yaitu upaya untuk membentuk diskursus yang tepat dan justifikasi yang benar atas ilmu-ilmu sufi. Adapun ketika Epistemologi masuk dalam ranah "tasawuf yang diteorikan" maka ia menjadi semacam diskursus yang dibuat oleh kaum sufi untuk menjelaskan tangga-tangga spiritual bagaimana prosedur yang tepat dalam menjalani tasawuf hingga mencapai ma'rifah.

Miswari mengemukakan tasawuf dalam dua prespektif yakni teori tasawuf dan tasawuf yang diteorikan. Menurutnya, jika Teori tasawuf lahir dari kajian para sarjana atas ajaran tasawuf maka Tasawuf yang diteorikan adalah upaya kaum sufi yang memperoleh pencerahan ma'rifah untuk membahasakan pengalamannya 
dalam bahasa-bahasa simbol yang terbatas sehingga menjadi ajaran tasawuf. (Miswari, 2016 :24-27).

Uraian tersebut setidaknya membantu untuk membedakan posisi antara kaum filsuf dan kaum sufi dalam memahami hakikat kebenaran. Jika kaum filsuf lebih terkonsentrasi pada bagaimana membuktikan sebuah kebenaran maka kaum sufi lebih terobsesi untuk menemukan kebenaran itu sendiri. Kaum filsuf akan merasa berdosa jika kebenaran tidak mampu dijelaskan. Namun kaum sufi tidak terlalu peduli, bagi mereka yang terpenting adalah menemukan kebenaran itu sendiri walaupun kemudian mereka tidak memiliki kemampuan untuk menjelaskannya. Jika kaum filsuf menggunakan akal untuk menjelaskan kebenaran, maka kaum sufi menggunakan hati untuk menemukannya.

Perbedaan-perbedaan tersebut kemudian mengantarkan kepada perbedaan epistemologi yang menjadi basis acuan pengetahuan. Jika epistemologi kaum filsuf lebih berbicara pada penalaran yang runtut dan tertib maka epistemologi kaum sufi berbicara tentang latihan spiritual yang runtut dan tertib. Dalam epistemologi kaum filsuf terdapat tahapan-tahapan tekhnis untuk menggali kepastian suatu kebenaran. Sedangkan epistemologi kaum sufi terdapat tahapan-tahapan praktis untuk menemukan suatu kebenaran. Jika kaum filsuf melakukan latihan intelektual (filsafat) untuk menguji sebuah kebenaran maka kaum sufi melakukan latihan spiritual (tasawuf) untuk menemukan kebenaran itu sendiri.

Epistemologi sufi dalam kajian Islam modern bukanlah hal yang baru. Abed Al-Jabiri misalnya mengidentikasi Epistemologi Sufi sebagai salah satu basis epistemologi keislaman ( Al-Jabiri, n.d:25l). Begitupun Mehdi Ha'iri Yazdi mencoba menalar Epistemologi Sufi sebuah usaha diskursus untuk menggugah validitas Ilmiah dari ilmu sufi (Mehdi Ha’iri Yazdi, 2003). Saifan Nur juga menggugah narasi ilmiah dari Epistemologi Sufi dengan meletakkan "karakteristik sufistik" dan "telaah rasional" atas ajaran kaum sufi sebagai basis ilmiahnya (Nur, 2012:135-136). Intinya, Epistemologi Sufi dimaknai sebagai upaya untuk mengilmiahkan ajaran kaum sufi.

Berbeda dengan ketiganya, M. Ainul Abed Syah menalar epistemologi sufi langsung pada pokok persoalan kesufian yaitu perangkat-perangkat kesufian, meliputi kontemplasi dzauq (metodologi dzauqū), untuk sampai kepada pengetahuan ma'rifah. Jika tiga nama sebelumnya yang hanya bergerak pada "diskursus ilmiah" yaitu upaya "pembenaran" dan "rasionalisasi" atas ma'rifah kaum sufi, M. Ainul Abed langsung menuju ke pokok epistemologi sufi yaitu "Bagaimana cara menemukan ma'rifah itu? (M. Ainul Abed Syah, 2012, 155-158)" Artinya, diskursus Abed Al-Jabiri, Mehdi Ha'iri Yazdi dan Syaifan Nur bahwa Epistemologi Sufi dimaknai sebagai wacana discourse atas ma'rifah kaum sufi dalam prespektif ilmiah kontemporer (Barat). Sedangkan M. Ainul Abed Syah memaknai 
Epistemologi Sufi sebagai wacana discovery bagaimana menemukan pengalaman ma'rifah itu sendiri.

Di sini, Diskursus Tasawuf akan berusaha mendamaikan dua kutub Epistemologi Sufi. Pertama adalah kelompok mengarahkan kajian Epistemologi pada prespektif diskursus ilmiah yang memiliki kecenderungan filosofis. Kedua adalah kelompok yang mengarahkan kajian Epistemologi Sufi pada bagaimana memaparkan jalan-jalan kesufian untuk menemukan ma'rifah. Intinya jika kelompok pertama berbicara bagaimana "membicarakan" ma'rifah maka kelompok kedua berbicara bagaimana "menemukan" ma'rifah.

Untuk itu, kajian Epistemologi ini akan mencoba berangkat dari tulisan A Sonny Keraf dan Michael Dua yang membagi pengetahuan kedalam Context of Discovery dan Context of Justification. Sederhananya, Context of Discovery adalah bagaimana pengetahuan ditemukan dan Context of Justification adalah bagaimana pengetahuan dijustifikasi atau divalidasi (Dua, 2006 :154-158). Dalam diskusi kali ini, Context of Justification dimaknai sama dengan Context of Discourse atau bagaimana mendiskursuskan dan menarasikan sebuah temuan (dalam hal ini capaian ma'rifah) hingga menjadi diskursus pengetahuan.

Hamzah Fansuri menuliskan pengalaman ma'rifah-nya dalam bentuk karya tulis secara gamblang. Ia menekankan bahwa tujuannya menuliskan pengalaman tersebut adalah untuk 'dipelajari' dan diamalkan oleh orang-orang yang belum mencapai ma'rifah. Artinya, Hamzah ingin mendiskusikan pengalaman ma'rifah yang diperoleh supaya dapat dimengerti, difahami dan diamalkan oleh mereka yang belum memperoleh pengalaman tersebut. Hamzah menuliskan dalam Asrâr al'Ârifinn:

"Adapun sementaranya yang belum bertemu dengan yang sempurna ber-ma'rifah, pandang pada lima belas bait. Adapun ini empat secawang (empat baris satu ikatan) pada sebuah bait. Jika tiada kamu faham pada bait lima belas ini lihat pada syarahnya pula. Karena sharah-nya itu perkataan ma'rifah Allah (Ada) dengan nyata dalamnya (Al-Attas, 1970: 234).

Ma'rifah Hamzah Fansuri dan hubungannnya dengan epistemologi sufi kontemporer diharapkan tidak hanya berbicara pada aspek pengetahuan, "Bagaimana membuktian kebenaran ma'rifah?' (context of discourse)" akan tetapi lebih jauh lagi, "Bagaimana menemukan pengalaman ma'rifah?" (context of discovery) dan "Bagaimana mengamalkan pengalaman ma'rifah?" (context of application). Jika diruntut dalam bentuk tabel, maka hirarki epistemologis ma'rifah Hamzah Fansuri akan terlihat seperti. 


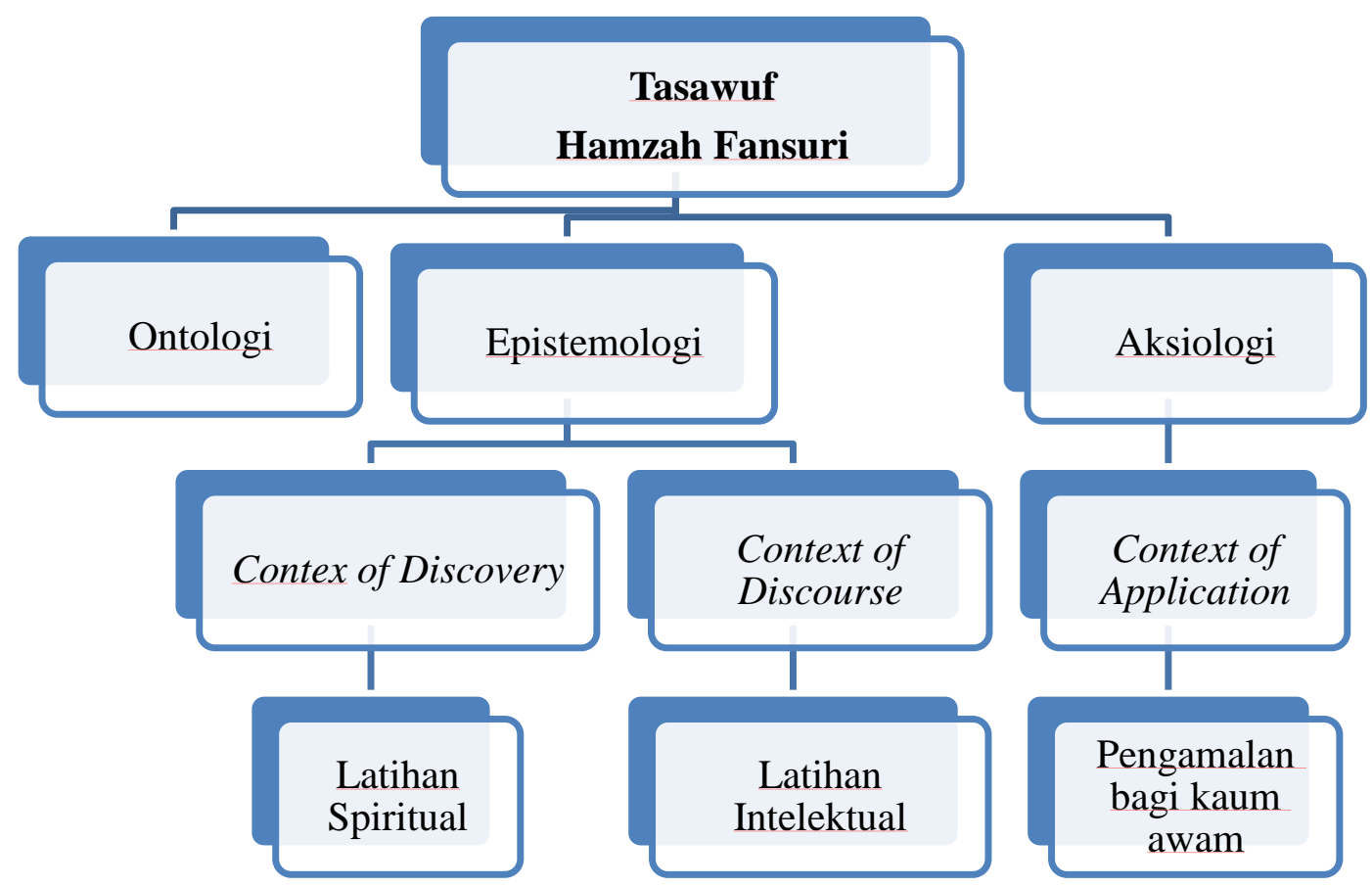

Grafik 1 Epistemologi Tasawuf Hamzah Fansuri

Epistemologi tasawuf dalam kesempatan ini akan dilihat dari sudut pandang context of discovery atau bagaimana mencapai puncak tasawuf. Hal ini dilakukan pertama karena Hamzah Fansuri lebih dikenal sebagai seorang sufi daripada seorang filsuf. Hamzah menekankan bahwa tujuan bertasawuf adalah untuk sampai kepada ma'rifah Allâh dengan metode menapaki jalan suluk untuk sampai kepada Allah. Kedua, untuk meringkas pembahasan dimana persoalan epistemologi Hamzah Fansuri secara context of discovery diarahkan pada empat tahapan spiritual yaitu, sharî‘ah, haqîqah, țarîqah dan ma'rifah. Sedangkan dalam context of discourse, apalagi ketika dibenturkan dengan filsafat modern akan sangat bersentuhan dengan tema-tema filsafat Islam yang sangat luas dan besar.

Untuk tahap ini, penulis belum terlalu intens menyentuh dimensi epistemologi dari ajaran tasawuf Hamzah Fansuri. Disini Epistemologi tasawuf Hamzah Fansuri diarahkan pada kajian sistematisasi 4 tangga spiritual yaitu sharĭ ah, țarĭqah, haqŭqah dan ma'rifah.

\section{Sharî‘ah}

Hamzah Fansuri dalam Sharb Sl-'Âshiqîn, menjelaskan makna sharî‘ah dalam dalam tiga klasifikasi. Pertama sharî́ah sebagai ritual meliputi syahadat, shalat, puasa, zakat dan haji. Kedua sharî‘ah sebagai tuntunan, meliputi perkataan Nabi, perbuatan dan taqrîr (persetujuan)-nya Nabi dan yang ketiga sharî́ah sebagai keyakinan (iman) yaitu dengan meyakini bahwa Nabi Muhammad adalah 
Rasulullah dan segala perkataan, perbuatan dan diamnya adalah kebenaran. Hamzah dalam hal ini menyimpulkan sharĭah sebagai ritual, keteladanan dan keimanan (Al-Attas, $1970: 307$ ).

Tuntutan untuk mengimani dan meneladani rasul harus dijalankan secara utuh dan tidak boleh setengah-setengah. Seorang tidak boleh hanya mengimani tapi tidak mengikuti risalah. Begitupun sebaliknya tidak boleh hanya mengikuti risalah tapi tidak mengimani. Menurut Hamzah ketika seorang meragukan kebenaran Rasulullah (baik kebenaran ia sebagai Rasulullah atau kebenaran risalah dan ajarannya) maka ia digolongkan sebagai orang kafir. Adapun mereka yang percaya pada kebenaran risalah, meyakini kewajiban namun lalai dalam melaksanakannya, maka bagi Hamzah mereka masih disebut muslim, akan tetapi muslim yang berdosa (Al-Attas, 1970:302). Artinya, jika seorang mengabaikan risalah maka ia akan menjadi fasik sedangkan jika mengabaikan keimanan (tidak beriman) maka ia akan menjadi kafir.

\section{Tarîqah}

Țarîqah secara bahasa adalah jalan yang ditempuh. Tarîqah dalam perkembangannya merujuk kepada jalan-jalan spiritual yang ditempuh kaum sufi untuk mencapai Tuhannya. Țarîqah yang difahami masyarakat umum biasanya berkenaan dengan lembaga-lembaga tasawuf yang bergerak dibidang pengembangan spiritualitas. Lembaga-lembaga tersebut biasa terstruktur dan memiliki perangkat serta metode yang berbeda satu sama lain walaupun samasama memiliki tujuan untuk perjumpaan dengan Tuhan. Kita mengenal lembaga Țarîqah (Tarekat) seperti Naqsabandiyah, Qadĭriyah, Rifầiyyah, Sadzĭliyyah dan lain-lain sebagainya. Kesemuanya itu menawarkan metode nya masing-masing dalam perjalanan suluk menuju Allah SWT.

Țarîqah yang ditulis dalam kitab Sharb al-'Âshiqîn, tidak merujuk kepada lembaga tasawuf (seperti Țarîqah Satariyah dan Țarîqah Naqsabandiyah) akan tetapi merupakan upaya yang dilakukan bersungguh-sungguh untuk memperoleh ma'rifah dari Allah. Terlihat bahwa titik tekan Hamzah lebih kepada tarîqah sebagai kesungguhan daripada tarîqah sebagai lembaga spiritual. Hal ini tidak sepenuhnya berbeda karena sejatinya lembaga-lembaga tasawuf juga berisi praktek-praktek spiritual yang menuntut kesungguhan dalam diri sang salik.

Țarîqah dalam pandangan Hamzah Fansuri adalah upaya untuk mencari keredhaan Allah, bersahabat dengan ahl ma'rifah, benci kepada yang dilarang Allah dan mengerjakan segala amal perbuatan baik semampunya. Selain itu, țarîqah juga adalah upaya untuk mengurangi makan, mengurangi berkata-kata yang tidak bermanfaat dan menjauhi mereka yang suka membual serta menjauhi kesia-siaan (Al-Attas, 1970: 305-307). Tarîqah adalah latihan abadi dalam ibadah dan berprilaku yang baik. 
Hamzah Fansuri membagi țarîqah ke dalam tiga tingkatan yaitu taubat, tark al-dunyâ dan tawakal. Taubat bagi Hamzah Fansuri adalah ketika seseorang berhenti dari berbuat dosa dan tidak kembali kembali lagi kepada dosa-dosa masa lalu. Adapun tark al-dunyâ dalam pandangan Hamzah adalah ketika seseorang tidak menumpuk harta yang melebihi kebutuhan wajar dalam dirinya. Sedangkan tawakal bagi Hamzah adalah ketika seseorang tidak memiliki keraguan sedikitpun (shak) kepada Allah (Al-Attas, 1970:305-307). Dalam literatur yang lain, tiga elemen tarekat Hamzah dinamai juga dengan maqâmât atau tangga-tangga spiritual.

Menurut Hamzah, haram bagi seorang ahl-haqîqah (sâlik) untuk meminta kepada selain Allah. Jikapun mereka terpaksa, maka mereka meminta sekedar kecukupan untuk makan pagi dan petang. Jika ada orang yang meminta lebih dari batasan tersebut maka sama saja orang tersebut sedang memenuhi perutnya dengan api neraka. Hamzah sangat menyukai mereka yang teguh hatinya untuk tidak meminta kepada selain Allah. Bahkan menurut Hamzah ketika seorang ahl al-ḥaqîqah tidak meminta kepada selain Allah (karena keteguhan tawakal-nya) hingga menyebabkan orang tersebut mati, maka bagi Hamzah orang tersebut mendapatkan kedudukan shahîd (Al-Attas, 1970:307).

\section{Haqîqah}

Haqîqah adalah tangga terakhir dari pengalaman spiritual. Hubungan antara haqîqah dan ma'rifah sering terdengar ambigu ketika dijelaskan dalam ranah ilmiah. Ada yang mengatakan bahwa keduanya sama, ada yang mengatakan keduanya terpisah. Hal ini tentu dapat dimaklumi karena diskurus ma'rifah adalah persoalan pengalaman spiritual dimana haqîqah dan ma'rifah hanya dapat difahami secara utuh oleh mereka yang telah telah mengalaminya. Lagi pula, masing-masing sufi akan menjelaskan keduanya dengan cara yang berbeda-beda sesuai dengan kondisi subjektif sufi yang bersangkutan. Intinya setiap sufi berbeda cara mereka memahami dan menjelaskan maksud haqîqah dan ma'rifah dan hubungan diantara keduanya.

Menurut Hamzah haqaîqah adalah puncak terakhir dari perjalanan Rasulullah SAW. Ini sejalan dengan hadits Nabi, "Al sharĭ ah aqwalı̌ wa al țarĭqah af'âl

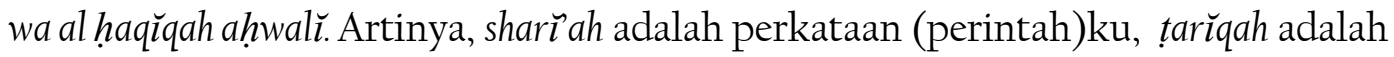
perbuatan (keteladanan)ku dan haqŭqah adalah keadaanku." Mereka yang telah mencapai haqîqah adalah mereka yang telah ber-ma'rifah. Dan mereka yang telah ber-ma'rifah adalah mereka yang telah mengenal Allah dengan sempurna kenal. Artinya, orang yang belum sampai pada mengenal Allah dengan sebenar-benar kenal (ber-ma'rifah) tidak akan mampu memahami haqîqah (Al-Attas, 1970:308). 
Hamzah membagi ahl haqiqqah ke dalam dua bagi. Pertama mereka yang melakukan amalan haqîqah secara moderat yaitu mereka yang tetap menjalani kehidupan keduniawian seperti bekerja, beristri dan beranak namun hatinya tidak terpaut kepada kesemua itu. Ketika pekerjaannya berhasil, kehidupan dirinya, istri dan anaknya makmur tidak membuat membuat ia bergembira hati. Begitupun ketika dirinya bangkrut, anak dan istrinya ditimpa malapetaka, pergi atau meninggal dunia, hatinya tidak merasakan kesedihan karenanya. Karena di dalam hatinya hanya ada Allah semata (Al-Attas, 1970: 308).

Adapun ahl haqiqqah model kedua, yaitu mereka yang dirinya telah sampai pada maqâm fanâ. Dimana totalitas rũhiyah-nya menjadikan dirinya tidak lagi berfikir selain Allah dan tidak ada lagi celah bagi fisik, jiwa maupun rüh-nya kepada Selain Allah. Mereka adalah model-model sufi yang menyerahkan dirinya secara utuh, baik fisik maupun ruhani dalam jalan tasawuf. Mereka tidak akan membiarkan kontemplasi dan hubungannya dengan Tuhan terganggu oleh persoalan-persoalan keduniawian. Mengenai ahl haqîqah golongan kedua ini, Hamzah menuliskan:

Adapun ahl haqiaqqah sebahagian lagi, dâim menyembah Allah, dan berahi akan Allah, dan mengenal Allah tunggal-tunggal, dan mengenal diri-Nya dan meniadakan diri-nya, mengesakan diri-Nya dan berkata dengan diri-Nya, fana dalam diri-nya dan baqâ dengan diri-Nya, benci akan dhahir diri-nya dan kasih akan bathin diri-Nya dan mencela dirinya dan memuji diri-Nya, jika duduk, duduk ia dengan diri-Nya, jika tidur, tidur ia dengan diri-Nya, jika jaga jaga dengan diri-Nya, jika berjalan berjalan ia dengan diri-Nya, tiada ia lupa akan diri-Nya karena Sabda Rasulullah, "man 'arafa nafsahu faqad 'arafa rabbahu" (Al-Attas, 1970:308-309).

\section{Ma'rifah}

Konsep ma'rifah Hamzah Fansuri tidak terlalu terlihat dalam kitab Sharb Al'Âshiqîn. Dalam bahasan tentang bab ma'rifah Hamzah hanya menyinggung dua pokok pembahasan, pertama mengenai perbedaan pandangan antara 'ulama (teolog dan ahli fiqh) di satu sisi dan kaum sufi di sisi yang lain berkenaan dengan masalah Allah Al-Muhĭt yaitu ketika Allah meliputi segala sesuatu. Para 'ulama percaya bahwa Allah meliputi semesta dengan Ilmu-nya. Namun menurut kaum sufi, Allah meliputi semesta dengan Ilmu dan Dzât-nya, karena Dzât tidak berpisah dengan ilmunya (Al-Attas, 1970:311). Akhirnya, jika dibuat diagram Epistemologi Tasawuf Hamzah Fansuri akan terlihat sebagai berikut: 


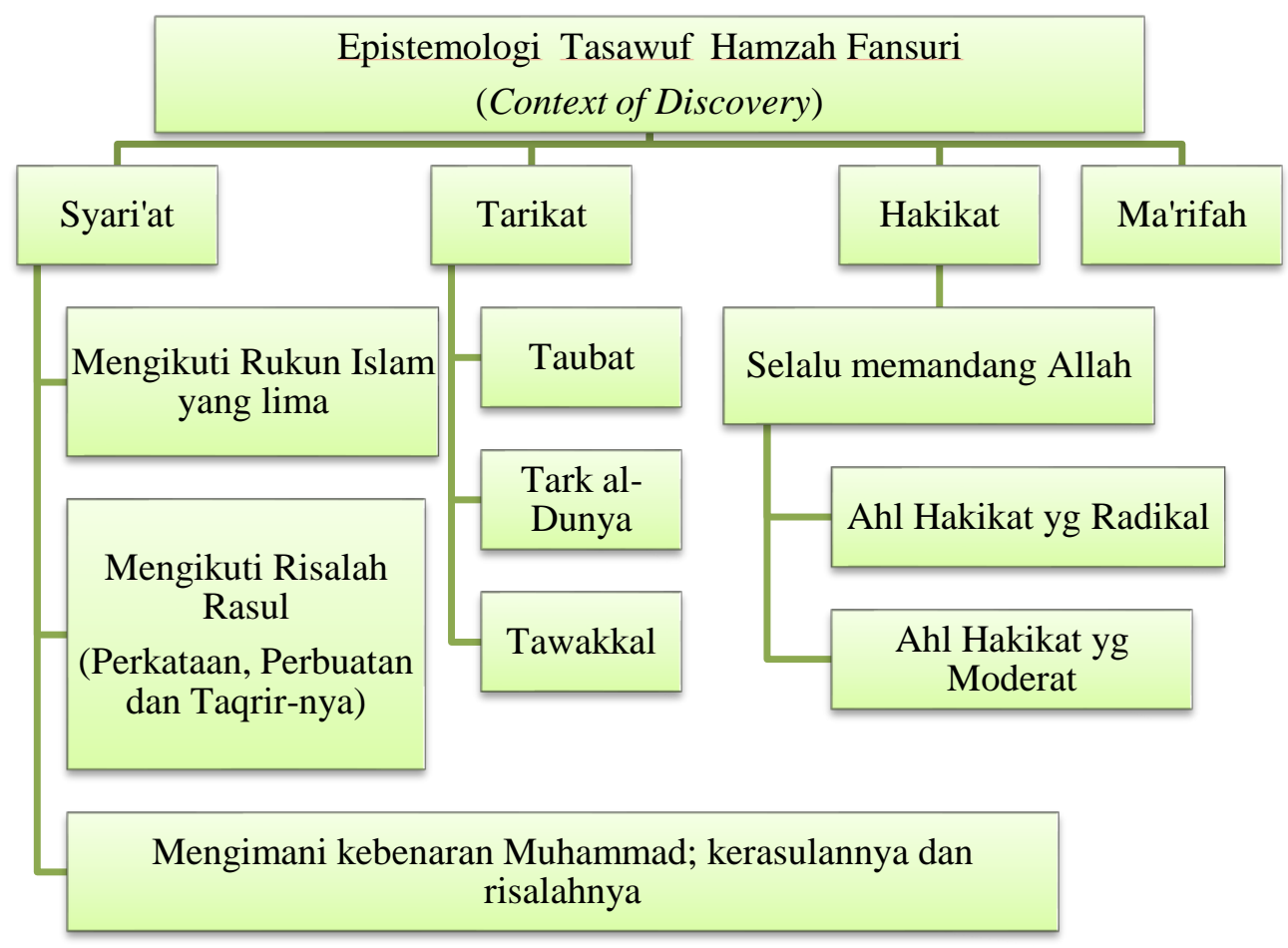

Grafik 2 Epistemologi Tasawuf Hamzah Fansuri

\section{KESIMPULAN}

Kajian ini dimulai dari pembagian epistemologi sufi dalam 2 konteks yaitu context of discovery dan context of discourse. Context of discovery berkenaan dengan metode suluk untuk mencapai ilmu tasawuf, sedangkan context of discourse berkenaan dengan metode berfikir falsafi yang digunakan untuk menganalisa dan mendiskusikan pengalaman dan pemahaman tasawuf para sufi.

Kajian ini menyimpulkan bahwa, "epistemologi ma'rifah” Hamzah Fansuri dalam kitab Sharb Al-ÂAshiqîn lebih mengarah kepada context of discovery yakni bagaimana kitabi ni memaparkan posisi epistemologi sufistik seorang Hamzah, bukan epistemologi filsafatnya, walaupun dalam kitab-kitabnya yang lain, Hamzah Fansuri juga membicarakan epistemologi tasawuf dalam context of discourse.

Kajian sederhana ini kemudian merangkum epistemologi tasawuf Hamzah Fansuri dalam kitab Sharb Al-Ashiqin ke dalam empat tingkatan sulük (perjalanan spiritual), yaitu Sharî‘ah, Tarîqah, Haqîqah dan Ma'rifah. Pertama, Sharî̀ah, dengan tiga point utama yaitu rukun Islam, tuntutunan Rasul dan keimanan. Kedua, tarîqah yang diposisikan sebagai maqâmât, dan diringkas kedalam taubat, tark al-dunyâ dan tawakkal. Ketiga haqiqâh dibagi kepada dua kategori pengamal, yaitu ahl ḥaqîqah yang ekstrim dan ahl haqîqah yang moderat. Dan keempat ma'rifah sebagai puncak 
dari perjalanan spiritual yang mengantarkan seorang hamba sampai dan mengenal akan Tuhannya.

\section{DAFTAR PUSTAKA}

Abdul Hadi. (1996). Hamzah Fansuri; Risalah Tasawuf dan Puisi-puisinya. Mizan.

Abdullah, H. (1987). Perkembangan Ilmu tasawuf dan Tokoh-tokohnya di Nusantara. Al Ikhlas.

Azra, A. (2004). Jaringan Ulama Timur Tengah dan Kepulauan Nusantara Abad XVII e XVIII, Akar Pembaharuan Islam di Indonesia. Kencana.

Brakel, G. W. J. D. and L. F. (1986). The Poems of Hamzah Fansuri. Foris Publication.

Dua, S. K. dan M. (2006). Ilmu Pengetahuan Sebuah Tinjauan Filosofis.

Hadi, A. (2011). Tasawufyang Tertindas; Kajian Hermeneutik terhadap Karya-karya Hamzah Fansuri. Paramadina.

Mehdi Ha’iri Yazdi. (2003). Menghadirkan Cahaya Tuhan. Mizan.

Miswari. (2016). Filsafat Terakhir. Unimal Press.

Muhammad Abed Al-Jabiri. (n.d.). Bunyah Al-'Aql Al-'Arabi; Dirasah Tahliliah Naqdiyah li Nudhum Al Ma'rifah fi Al Thaqafah Al Arabiyah. Markaz Al-Dirasah Al Wahdah Al Arabiyah.

Nur, S. (2012). Epistemologi Sufi dan Tanggung Jawab Ilmiah. Kanz Philosophia : A Journal for Islamic Philosophy and Mysticism, 2(1). https://doi.org/10.20871/kpjipm.v2il.27

Saghir, W. M. (1996). Tafsir Puisi Hamzah Fansuri dan Karya-karya Shufi. Khazanah Fathimiyah.

Said, M. (1981). Aceh Sepanjang Abad. 1.

Shah, M. A. A. (2012). Epistemologi Sufi Perspektif Al-Hakim Al-Tirmidzi. Kanz Philosophia : A Journal for Islamic Philosophy and Mysticism, 2(1), 153-182.

Simuh. (2002). Tasawuf dan Perkembangannya. Raja Grafindo Persada.

Syarifuddin. (2011). Wujudiyah Hamzah Fansuri dalam Perdebatan Para Sarjana. Almahira. 
Syed Mohammad Naquib Al-Attas. (1970). The Mysticism Of Hamzah Fansuri. University of Malaya. 